DOI: $10.15393 /$ j9.art.2019.6201

УДК 821.161.1.09

Н. В. Пращерук

Уральский федеральный университет имени первого Президента России Б. Н. Ельцина (Екатеринбург, Российская Федераиия)

pnv1108@gmail.com

\title{
Диалог с Ф. М. Достоевским в романе Е. Р. Домбровской «Путь открылся... Чехов. Духовные странствия Тимофея диакона»
}

Аннотация. В статье исследуется диалог с Ф. М. Достоевским, который разворачивается в христианском метаромане Е. Р. Домбровской «Путь открылся... Чехов. Духовные странствия Тимофея диакона». Показывается, что диалог носит масштабный, системный и многоаспектный характер. Он ведется на всех уровнях художественной системы произведения: авторской установки, метода, жанра, сюжета, системы персонажей и позволяет писателю осуществить грандиозный герменевтический опыт. В диалогическом соотнесении Чехова и Достоевского выявляется, что этих двух классиков XIX в. роднит верность евангельскому духу, которая помогает обоим художникам быть богословски точными / корректными в оценках и акцентах. Однако если Достоевский, захваченный прежде всего проблемой разрушения религиозного сознания и испытания человека на путях свободы без Бога, в своих произведениях прямо «проговаривает» принципы и смыслы христианского вероучения, то чеховский духовный реализм, высвечивающий «движение сущностного слоя» через призму повседневного существования человека, скорее «дышит безмолвием, живет внутренним словом». И, кроме того, Чехов как сын своего времени острее чувствует опасность фарисейства. Диалог с Достоевским осуществляется не только в филологических штудиях главного героя, но и в прочтении судеб персонажей романа, в осмыслении духовного состояния современной России. В статье - с опорой на размышления Е. Р. Домбровской - впервые указывается, что понимание Чеховым красоты / Красоты трактуется и как продолжение известного завета Достоевского, и как обогащение его новыми сокровенными смыслами.

Ключевые слова: Чехов, Достоевский, диалог, христианский метароман, христианский реализм, сюжет, герой, понимание Красоты

Об авторе: Пращерук Наталья Викторовна - доктор филологических наук, профессор кафедры русской и зарубежной литературы, Уральский федеральный университет имени первого Президента России Б. Н. Ельцина (ул. Мира, 19, г. Екатеринбург, Российская Федерация, 620002)

Дата поступления: 14.03.2019

Дата публикации: 18.10.2019

(C) Н. В. Пращерук, 2019 
Для цитирования: Пращерук Н. В. Диалог с Ф. М. Достоевским в романе Е. Р. Домбровской «Путь открылся... Чехов. Духовные странствия Тимофея диакона» // Проблемы исторической поэтики. - 2019. - Т. 17. № 4. - C. 345-365. DOI: 10.15393/j9.art.2019.6201

$\mathrm{C}$ овременный прозаик, эссеист Е. Р. Домбровская - автор статей, объединенных духовной проблематикой, масштабных по замыслу и воплощению книг «Весна души. Страницы жизни рабы Божией Анны» и «Воздыхания окованных. Русская сага» ${ }^{1}$ Ее новое произведение «Путь открылся... Чехов. Духовные странствия Тимофея диакона» ${ }^{2}$ написано в редком для нынешней литературы жанре христианского метаромана. Главный сюжет, который связан одновременно с историей становления героя, его аскетическим опытом и постижением феномена Чехова, развертывается в жанре романа воспитания и духовных странствий героя. «Переводя» читателя из духовных глубин в сферу творчества, философии и критики, автор четко придерживается критериев и мотивировок, выработанных практикой духовного делания героя. Такая методология помогает открыть в Чехове подлинно христианского писателя. Подобный герменевтический опыт был бы вряд ли возможен, если бы на протяжении всего романа автор и его герой не обращались к Ф. М. Достоевскому - художнику, религиозному мыслителю, «реалисту в высшем смысле».

Если иметь в виду критику и литературоведение, то проблема «Чехов и Достоевский» имеет давнюю историю. И сопоставление классиков, как известно, начиналось с их «великого противостояния» [Громов, 1989], зафиксированного известным метафорическим суждением И. Анненского: «И неужто же, точно, русской литературе надо было вязнуть в болотах Достоевского и рубить с Толстым вековые деревья, чтобы стать обладательницей этого палисадника... <..>. Я чувствую, что больше никогда не примусь за Чехова. Это сухой ум, и он хотел убить в нас Достоевского...» [Анненский, 1979: 460]. Правда, уже тогда, «смягчая» столь жесткое противопоставление и осмысляя феномен того и другого писателя в ключе собственной философии, Л. Шестов посчитал Чехова своим экзистенциальным предшественником, 
усмотрев сходство писателя и героя «Записок из подполья» (см.: [Шестов]). Как отмечал С. Г. Бочаров, «чеховская “адогматическая и неиерархическая” картина мира подходила Шестову, выступившему с протестом против классической догматической философии (гегелевского типа)» [Бочаров: 150]. Безусловно, крайности заявленных точек зрения на сегодняшний день скорректированы. Есть целый ряд работ, в которых предпринимается попытка сопоставить творчество и авторскую позицию Чехова и Достоевского. Чаще всего это исследования, в которых обнаруживаются тематические и проблемно-содержательные переклички, определенное сходство / несходство пафоса, продолжение Чеховым открытий предшественника в поэтико-эстетической сфере художественного творчества ${ }^{3}$.

Вместе с тем при признании ценности отдельных сопоставлений и анализов произведений, следует отметить, что они носят скорее частный характер, не выходят на глубинные основания, обусловливающие онтологию и аксиологию художественных миров обоих авторов.

В отличие от широкого круга таких исследований, в романе Е. Р. Домбровской диалог с Достоевским, развертывающийся на всем протяжении объемного текста, носит масштабный и системный характер. Он напрямую связан со сложной жанровой природой произведения и ведется на различных уровнях авторского сознания в целом и создаваемого им художественного мира - от исходных установок, проблематики, сюжета и системы персонажей до структурных закономерностей и образных перекличек. Однако самое главное - то, что подобная многоплановость осуществляется с опорой на общее, христианское, видение творчества обоих художников и в методологии «растущих контекстов» (Домбровская), предполагающей постепенное погружение в духовную проблематику произведений и развертывание ее - с приращением все новых и новых смыслов.

Следует упомянуть о самом жанре книги, поскольку уже в нем в полной мере сказывается установка автора на диалогичность. Сложная и специфическая жанровая природа произведения была достаточно подробно проанализирована в нашей статье «Христианский метароман Е. Р. Домбровской 
“Путь открылся...”» [Пращерук, 2018b]. В частности, с опорой на теоретические труды В. Н. Захарова, В. Б. Зусевой-Озкан, Д. Ловенкрона (D. H. Lowenkron) и других исследователей ${ }^{4}$, подтвердилась не только «метароманность» книги Е. Р. Домбровской. Существенно уточнить авторскую жанровую номинацию помогли труды В. Н. Захарова об итоговом романе Ф. М. Достоевского. Ученый обосновал оригинальную жанровую концепцию «Братьев Карамазовых» как романа романов и христианского метаромана: «Роман романов Достоевского был синтезом самых разнообразных художественных и нехудожественных жанров. Вместе с тем в русской литературе родился новый, небывалый тип романа - христианский метароман, в котором христианское миропонимание автора представлено как страстная драма людей и идей» [Захаров, 1997а: 226]. И хотя говорить о «Братьях Карамазовых» как прецедентном тексте для романа Е. Р. Домбровской, вероятно, преждевременно, - нет никаких сомнений в том, что ключевое произведение русской культуры является одним из авторитетных субъектов диалога, развертывающегося в книге современного писателя. Включая многие жанровые разновидности (роман воспитания, семейный роман, романстранствие, идеологический роман, роман о романе и др.), объединяя разнородный стилевой и повествовательный материал, а также моделируя сквозную ситуацию духовно-творческого процесса - написания исследования о Чехове - книга Домбровской внутренне целостна. Это достигается именно потому, что «концы и начала» обретаются только, по образному выражению самого автора, у «подножия последнего рубежа - Евангелия с его Духом и заповедями» (Домбровская). И это свидетельствует о продолжении жизни жанра христианского метаромана в русской литературе.

Во многом в диалоге с Достоевским и его итоговым романом складывается методология постижения / прочтения героем чеховского феномена. Здесь уместно вспомнить как принципы диалогического общения, включая его необходимые составляющие - «вживание» и «вненаходимость» [Бахтин: 334], так и сущностную перекличку, обусловленную «христоцентризмом» обоих авторов. Имеется в виду смысловая доминанта «Братьев 
Карамазовых», обозначенная эпиграфом: «Истинно, истинно говорю вам: если пшеничное зерно, пав в землю, не умрет, то останется одно; а если умрет, то принесет много плода» (Ин. 12:24). Главная мысль эпиграфа проходит через весь текст романа. Например, строки из Евангелия встречаются в отчасти переформулированном виде в 6-й книге в главе, где представлено жизнеописание старца Зосимы:

«Нужно лишь малое семя, крохотное: брось он его в душу простолюдина, и не умрет оно, будет жить в душе его во всю жизнь, таиться в нем среди мрака, среди смрада грехов его, как светлая точка, как великое напоминание» ${ }^{5}$.

Точное цитирование евангельского стиха мы можем прочесть в главе, где старец Зосима благословляет Алёшу на служение миру. Такое наставление связывается в дальнейшем не только с личным путем Алёши, который послан на службу ближним, отвергаясь самого себя, но и с предназначением «русского инока» в целом, который призван быть примером жертвенной, созидающей любви Христовой.

«Путем зерна», сокрушая свое сердце в подвиге смирения, идет и герой Е. Р. Домбровской. В том, как Тимофей проживает события собственной жизни, как оценивает окружающих людей, современный церковный быт, как понимает и осуществляет собственно филологические штудии, которые носят, в том числе, и характер духовных испытаний и обретений, воплощается любимая и справедливая мысль автора о том, что только в состоянии «сокрушенного сердца» человек способен на подлинное понимание и подлинные открытия:

«Здесь, в этом пункте - всё самое главное! - сказал себе Тимофей. - Центр жизни, центр спасения - сокрушенное сердце человеческое. Здесь все ключи к верным пониманиям, слышаниям и толкованиям чеховских образов - и не только чеховских, но и вообще русской классики <...>. А потому, если критик, может быть, сам и никакой не подвижник, но человек, имеющий в своей сокровенности это драгоценное во Христе сокрушенное сердце, он непременно услышит духовно родственное и в другом, - в текстах...» (Домбровская). 
В состоянии «сокрушенного сердца» герой собирает по крупицам открывающиеся ему как дар зерна смыслов:

«...теперь надо было не выронить неожиданно упавший к нему в руки драгоценный дар, драгоценное слово, не заболтать его, не залить и не замазать его своими собственными сиропами измышлений» (Домбровская).

Обильно политые сострадательными слезами и упитанные почвой любви, эти зерна прорастают, набирают силу, и одновременно с этим - растет и наше понимание чеховского творчества. Новозаветный образ зерна, которое «может принести много плода», становится лейтмотивным, присутствует в книге как прямо, так и имплицитно. В третьей главе речь идет о «растущих контекстах» (Домбровская), знание которых дает возможность погружения в глубины чеховского мира. А в конце книги автор пишет о том, что и самому слову Чехова «предназначалось расти, дожидаясь своего времени, настаиваться в ожидании тех сердец, в которые оно сможет укануть и загореться в них звездой» (Домбровская).

Завершающим аккордом в развитии темы новозаветного зерна (смерти, побеждаемой воскресением) в «Братьях Карамазовых» становится эпилог - сцена похорон Илюшечки и речь Алёши. Как справедливо заметил К. Степанян, «в финале своего последнего романа Достоевский осуществил главную цель христианства - победу над смертью» [Степанян: 723].

«- Карамазов! - крикнул Коля, - неужели и взаправду <...> мы все встанем из мертвых, и оживем, и увидим опять друг друга, и всех, и Илюшечку? - Непременно восстанем, непременно увидим и весело, радостно расскажем друг другу всё, что было...» (Д30; 15: 197).

С этим эпизодом прямо коррелирует фрагмент из романа Домбровской, рассказывающий о смерти матери главного героя и о том, какой сон видит он, скорбя по умершему самому близкому человеку:

«В ночь на двадцатый день Тимофей в первый раз увидел во сне мать. Она была в схиме, в правой руке держала высокий и тонкий, как у мучеников на иконах, крест, стояла ровно и крепко - никакого паралича. И каким же было её лицо! Тимофей 
и под куколем разглядел, как она сияла: “Я — Евфросинья! Я — Евфросинья!” - совершенно живая, реальная, осязаемая, несомненно, молодого возраста, ликующая, повторяла она Тимофею своё новое имя, словно он его ещё не распознал, и глубоко-глубоко заглядывала при этом ему прямо в сердце» (Домбровская).

Сходство, обусловленное сокровенным пониманием переживаемого героями опыта, акцентируется продолжением сна, в котором мать встречает / обретает своего сына, погибшего еще во младенчестве:

«Тут откуда-то прибежал маленький мальчик, сразу по-свойски обхватил ноги матушки, и она, последний раз глянув в Тимофея - теперь с неописуемой любовью, повернулась, взяла за руку малыша и, опираясь на крест, пошла с ним куда-то вдаль, быстро тая в непроницаемо-молочном, жемчужно-светящемся, неземном тумане» (Домбровская).

Как не вспомнить для сравнения наставления Зосимы, которые он адресует матери, скорбящей по умершему сыну-трехлеточке в главе «Верующие бабы», и горе семьи, потерявшей Илюшечку, и речь Алёши на похоронах о непременном воскресении!

Диалог продолжается на уровне расстановки персонажей, осмысления их судеб и личностей. Уже в самом начале (в прологе к роману) при первом же упоминании главного героя Тимофея, молодого человека, глубоко верующего, воцерковленного и имеющего духовного наставника - старца, диакона и филолога-исследователя в одном лице - автор отсылает нас к Достоевскому. Характеризуя напряженность интеллектуальных усилий Тимофея, Домбровская, с одной стороны, вспоминает Ивана Карамазова, жаждавшего, как известно, «мысль разрешить», а с другой, намечает сквозную линию неожиданных персонажных перекличек в мирах обоих гениев, ведущих при системном осмыслении в сферу антропологии художников, питающуюся в обоих случаях живым источником христианской / православной традиции:

«Почему-то в памяти Тимофея всплыл “Идиот", с которым тут же мгновенно -сблизился и чеховский Николай Алексеевич Иванов, возможно, и Мисаил из “Моей жизни”. Все ведь они на людях и в глазах людей были... идиотами» (Домбровская). 
Тем самым автор сразу же открыто указывает на одного из постоянных спутников героя в его духовных странствиях и филологических штудиях. «Если Алёша Карамазов - ранний человеколюбец, то Тимофей - ранний мыслитель», заметила Домбровская в одном из своих писем 6 , продолжая линию сопоставлений уже за пределами собственно романа. Это один из примеров авторефлексии, помогающий прояснить не только персонажное родство и причину такового, но и сюжетно-композиционные схождения. В самом деле, Тимофей и старец Севастиан, призванные в романе Домбровской раскрыть тему подлинного наставничества / ученичества, могут быть органично соотнесены с другой персонажной парой из последнего романа гениального предшественника Зосимой и Алёшей.

Можно заметить не только сходство системы персонажей, но и самого характера взаимоотношений героев, сердечной привязанности их друг к другу, вырастающей из духовного родства. Одной из кульминационных глав в раскрытии темы становится 28-я глава, в которой описана прощальная встреча Тимофея и старца Севастиана, уже очень немощного и физически слабого, в келье последнего. Подобно тому как в «Русском иноке», здесь все пронизано любовью и окрашено редкой в современной литературе умилительной интонацией [Захаров, 2009].

Дарение старцем четок (сотницы), сплетенных им самим в лагере, можно трактовать метафорически и символически как знак возрождающейся духовной преемственности, без которой подлинная жизнь мертва. Символично и то, что Тимофей благословляется в скором будущем на хиротонию, в отличие от Алёши, отправленного Зосимой в мир. Состояние Церкви таково, что она нуждается в пастырях, подобных Тимофею. Это как будто Алёша, испытавший себя в миру, возвращается к единственному своему предназначению. Очень важно, что в этой главе, напитанной любовью во Христе двух сердец, слышащих и понимающих друг друга, есть отсылка к сочинению митрополита Антония (Храповицкого) «Пастырское изучение людей и жизни по произведениям 
Ф. М. Достоевского» [Храповицкий]. Именно эту книгу получает Тимофей в дар вместе с сотницей тогда, когда он на пике своих терзаний стремится разгадать самое главное в чеховской антропологии, совокупно и органично с тем источником, которым она питается. Труд митрополита Антония (Храповицкого), сфокусированный на героях Достоевского, обладающих даром возрождать других людей, включается в напряженное диалогическое поле размышлений героя. Во-первых, в обращении к сочинению митрополита, который был знаком с Достоевским, много с ним беседовал, а потом немало размышлял и писал о его творчестве, углубляется тема духовной преемственности, подчеркнутая еще и сходством личностей митрополита Антония и литературного старца Севастиана, их чистосердечием и открытостью. А, во-вторых, через осмысление труда митрополита в соотнесении с героями, о которых он пишет, Тимофею открываются тайны и глубины чеховской антропологии:

«Чистосердечие и не-самовлюбленность (поистине гремучая смесь: ни чистосердечие при самовлюбленности, ни отсутствие самолюбия без чистосердечия - в разъединении - не могли бы никогда действовать на других спасительно; только в паре), по мнению владыки Антония, были свойственны Алёше, безусловно, старцу Зосиме, Илюшечке. И Тимофей теперь смело добавил бы сюда и грешного Митю Карамазова, которому, как он теперь ясно понимал, сильнее всех были присущи эти черты, сокрытые в глубинах его сердца, а потому и та возрождающая сила...» (Домбровская).

Отвечая на вопрос, «близка ли была Чехову тема духовного пробуждения человека и есть ли у него, как и у Достоевского, возрождающие, призывающие к самоуглублению личности» (Домбровская), Тимофей подробно останавливается на рассказе «Попрыгунья», полемизируя своей интерпретацией, как это явствует из контекста, с оценкой О. А. Николаевой, имя которой в тексте не называется [Николаева: 116-134]. Он приходит к выводу, что «возрождатели», подобно не только старцу Зосиме, но и Соне Мармеладовой, Миколке или Дымову и Мисаилу, спасительно воздействуют на других совсем не потому, что преуспели в искусстве проповеди и совершенстве 
риторики. Причина спасительного воздействия этих героев на окружающих - в великом даре, обретенном «школой сокрушения» - открывать свое смиренное и чистое сердце другим:

«...всё личное спасение человека и в связке с ним возрождающее действие такого человека на других на том и основано: на искреннем, выстраданном, не формальном самопознании своей греховности, покаянии и плаче о грехах, сокрушающем сердце, на самоукорении и следующем за тем, а точнее, в самом том плаче и совершающемся в человеке начале его исцеления...» (Домбровская).

Более того, автор полагает, углубляя наше понимание чеховской антропологии, что «не человек человека возрождает, а Свет Христов, поселившийся в смиренном сердце человека, Божественные энергии, к которым приобщается его чистая душа. <...> Это возрождающее дыхание Христова подобия в человеке гениально выписано в “Дуэли” (преображенные покаянием супруги Лаевские и фон Коррен), присутствует в “Моей жизни”. <..> чудо возрождения и преображения души начинает совершаться и в “Попрыгунье” (Домбровская).

Сущностные схождения двух гениев, обусловленные общим - евангельским - критерием понимания человеческой природы, обнаруживаются в их устремленности «при полном реализме найти в человеке человека» (Д30; 27: 65). В прямой перекличке с известным суждением Достоевского разворачиваются размышления Домбровской о героях Чехова и об авторском к ним отношении:

«Суд Божий рассматривает не дела, но намерение, с которым они совершаются. Вот это и есть и духовный, и творческий символ веры Чехова - краеугольный камень его понимания жизни и человека, на котором он твердо стоит, призывая и читателя не спешить с судами и приговорами, ориентируясь не на бросающиеся в глаза буквы, но слушать и слышать глубинную жизнь человеческих сердец, а в ней - главное: сокровенную, пусть и бессловесную, и самим человеком не всегда осознанную, но драгоценную и спасительную тоску по Богу и по подлинной жизни в другой, подлинной реальности - не на земле изгнания» (Домбровская). 
Такая позиция Чехова-художника, по мнению автора, глубоко укоренена в святоотеческой традиции:

«Чехов, вероятно, по исключительному дару Божиему его гению, был чудесным образом привит к этой исихастской традиции (во главе еe - свт. Григорий Палама), которой было свойственно находить семена Логоса даже в самых, казалось бы, “неподходящих" особях.

Мучительно ищет связующую мысль для уврачевания своей расколотой души и восстановления разорвавшихся связей жизни умирающий профессор медицины Николай Степанович герой “Скучной истории”, с трудом вспоминающий в конце концов спасительное слово “Бог”; мечется душа Маши Прозоровой в “Трех сестрах”... <..> он пишет жизнь и человека, как он есть, во всей его бездонной экзистенциальной противоречивости, он пишет и пустоту души, и ее томление, и даже ее смерть (“Ионыч”), подводя тем самым читателя и зрителя к мысли о Боге, места Которого в душе человека никто и ничто заменить не способно» (Домбровская).

Автор романа вспоминает Достоевского (в частности, его утверждение о том, что «человек - существо переходное») и тогда, когда Тимофею в его штудиях открывается правда «двойного устроения» чеховских героев:

«...и божественный Давид, который принижает человеческую природу, и премудрый Соломон, который возвеличивает ее не противоречат друг другу. <..> во многих местах Священного Писания мы обнаруживаем подобное противоречие, в котором, на самом деле, содержится и единомыслие, и согласие. Причина же в том, что человек имеет двойное устроение и вел двоякую жизнь - до преступления заповеди и после. Потому человек существо промежуточное (вспомним подобное слово Достоевского!). След той и другой жизни присутствует в нем. Но человек, если пожелает, может и восстановиться, и обожиться, а может и склоняться в сторону греха: может звереть, становиться скотоподобным и “никакая необходимость не удержит его” (Домбровская).

В одной из самых эмоционально сильных глав, рассказываюей о кончине матери героя, автор обогащает чеховскую 
антропологию новыми смыслами, идя от понимания «двойного устроения» человека к обретению / необретению им «двойного видения» (Домбровская).

С опорой на евангельскую и святоотеческую традиции, а также реализуя на всех уровнях субъектной организации (автор-повествователь-герои-читатель) принципы диалогического общения, Домбровская перечитывает заново большой корпус чеховских произведений. Обобщая свои наблюдения и делая это в строгом соответствии с критерием, выработанным на протяжении многих лет писательского труда, она закономерно выходит к осмыслению чеховского метода, называя его духовным реализмом. Следует сразу отметить, что, предлагая этот термин, писатель исходит из апостольского определения духовного ${ }^{7}$, многократно ранее ею обоснованного. Духовныцй в данном случае синонимичен христианскому. В своих размышлениях Домбровская опирается, в том числе, на известное высказыване Достоевского о "реализме в высшем смысле» (Д30; 27: 65). Ее выводы о методе Чехова формулируются в прямом соотнесении с методом Достоевского и в русле наиболее авторитетных исследований современной достоевистики, а именно работы В. Н. Захарова «Христианский реализм в русской литературе (постановка проблемы)» [Захаров, 2001]. Вместе с тем, поясняя в религиозно-философском ключе собственное терминологическое предпочтение в номинации чеховского метода, Домбровская замечает, что

«Чехов <..> был художником не лгущим - списателем не буквы жизни, а искателем и исследователем ее духа, то есть духовным и подлинно христианским реалистом. <...> Христианство по своей корневой системе - и есть глубокий и честный реализм во взгляде на жизнь, на человека, на все мироустроение, взгляд, которому категорически, принципиально чужда мечтательность, уводящая человека от того, что святые отцы именовали путем трезвения и внимания в дебри того, что те же отцы именовали погибельной духовной прелестью. Так что не христианский реализм, а духовный, истинный реализм, внимающий не только видимому, слышимому и руками осязаемому, но и всем тем подлинным, скрытым и невидимым процессам, происходящим в жизни и одной души, и многих - вплоть до всего человечества» (Домбровская). 
Думается, что здесь нет смысла уклоняться в терминологические споры, поскольку речь в данном случае идет не о дефинициях, а о существе понимания метода того и другого художника. И в этом отношении поразительна, но и закономерна диалогическая перекличка позиций - при всей их яркой личностной окрашенности - автора книги о Чехове и ученого-достоевиста.

Так, В. Н. Захаров в своей работе замечает: «Достоевский поведал мрачную историю: что может быть ужаснее смерти обиженного ребенка? Но откуда тогда возникает неуместная (с точки зрения “евклидова ума”) радость приглашенных на елку к Христу? И отчего в последнем романе Достоевского ликуют над гробом почившего в Бозе старца Зосимы званые и избранные на брачном пире в Кане Галилейской? Все плохо - чему они радуются? Откуда, чем вызвано их умиление? Ответить на эти вопросы - понять характер и сокровенную тайну русской литературы. В чем эта трудно постигаемая и изрекаемая тайна, сказал сербский святой и богослов XX в. преподобный Иустин в своей книге о Достоевском: “Тайна и сила России в Православии...”» [Захаров, 2001: 19-20].

«Каким образом удаётся Чехову воплощать эту изумительную, богословски выверенную антиномию, это таинственное знание, что счастья нет, хотя оно... есть? <...> Чехов отвечает ...точно опять же и с точки зрения самого строго богословия - по Писанию: “Вечер водворится плач, и заутра радость” [Пс. 29], по Слову Самого Спасителя: "В мире скорбни будете" [Ин. 16:33] и "Увижу вас, и возрадуетесь, и радости вашей никто не отнимет у вас" [Ин. 16:22]. Это один из самых пронзительных примеров евангельских антиномий, которые воспринимаются таковыми <...> земной рассудочной логикой, потому что она не в силах одолеть евангельскую истину о скорби <...> как родительнице радости и счастья», - пишет Е. Р. Домбровская, поддерживая мысль В. Н. Захарова о непротиворечивой антиномике евангельских истин, не дающейся плоскому евклидову уму.

Наконец, в романе очень тонко почувствовано и обозначено ранее никем не отмеченное чеховское понимание красоты / Красоты. В его понимании видится и следование известному 
завету Достоевского о Красоте, которая «мир спасет», и обогащение этого завета новыми сокровенными смыслами, новыми смысловыми акцентами. Они связаны с принятием красоты Креста в ее трагической антиномичности, а также с утверждением «смиренного несения крестов, от Бога данных человеку». Приводя цитату из чеховских «Врагов» о «едва уловимой красоте человеческого горя, которую не скоро еще научатся понимать» и увязав этот рассказ с другими произведениями художника, писательница заключает:

«...Правда и Красота Христова, в человеческой жизни может быть явлена лишь как “красота человеческого горя”, красота страдания. Оно - и есть красота, потому что оно - правда о состоянии человека и о том, как должна строиться его земная жизнь, - правда и красота Креста. Потому всякое своевольное уклонение от Правды крестного пути, от смиренного несения крестов, от Бога данных человеку в обстоятельствах и “лямках" его жизни, есть падение в ложь, в безобразие, в смерть. Подлинная Христова Красота может существовать только в предельной правдивости и умирает, задыхается при малейшей лжи в мирской правде без Бога, в совести без Бога, которая есть вещь страшная, по слову Достоевского, погибельная» (Домбровская).

Таким образом, диалог с Достоевским в постижении личности и творчества Чехова, осуществленный в романе Е. Р. Домбровской, оказался столь многоаспектен, что более глубокая разработка каждого из аспектов могла бы стать темой отдельного литературоведческого сюжета. Однако уже в первом приближении очевидно, что двух классиков XIX в. роднит верность евангельскому духу, которая помогает им быть богословски точными / корректными в оценках и акцентах. Очевидно и другое. Если Достоевский, захваченный прежде всего проблемой разрушения религиозного сознания и испытания человека на путях свободы без Бога, в своих произведениях прямо «проговаривает» принципы и смыслы христианского вероучения, то чеховский духовный реализм, высвечивающий «движение сущностного слоя» через призму повседневного существования человека, скорее, «дышит безмолвием, живет внутренним словом» ${ }^{8}$. И, кроме того, Чехов как сын своего времени острее чувствует опасность фарисейства. 


\section{Примечания}

1 Домбровская Е. Воздыхания окованных. Русская сага. Ontario: Altaspera Publishing, 2012. 718 с.; Домбровская Е. Весна души. Страницы жизни рабы Божией Анны. М.: У Никитских ворот, 2016. 512 с.

2 Домбровская . Путь открылся... Чехов. Духовные странствия Тимофея диакона [Электронный ресурс] // Портал «Проза.py». URL: http://www. proza.ru/avtor/skityanka\&book=41\#41 (10.11.2017). Далее ссылки на это издание приводятся в тексте статьи по этому источнику.

3 См., напр.: [Карасев], [Карякин], [Кубасов], [Назиров], [Полоцкая], [Чотчаева] и др.

4 См.: [Захаров, 1997a, 1997b, 2013], [Зусева-Озкан, 2012, 2014], [Озкан, 2013], [Lowenkron].

5 Достоевский Ф. М. Полн. собр. соч.: в 30 т. Л.: Наука, 1976. Т. 14. С. 266. Далее ссылки на это издание приводятся в тексте статьи с использованием сокращения Д30 и указанием тома, страницы в круглых скобках.

6 Домбровская Е. Р. Письмо к Н. В. Пращерук. От 10.10.2018 (из личной переписки, не опубликовано).

7 «По учению Апостола Павла, духовный человек четко отличается от человека душевного. Духовным является тот человек, который имеет в себе действие Святого Духа, тогда как душевным человеком является тот, у кого есть душа и тело, но кто не стяжал Святого Духа, дающего жизнь душе <...> (1 Кор. 2:14-15)» [Иерофей (Влахос): 9].

8 Домбровская Е. Р. Письмо к Н. В. Пращерук. От 25.02.2019 (из личной переписки, не опубликовано).

\section{Список литературы}

1. Анненский И. Ф. Книги отражений. - М.: Наука, 1979. - 679 с.

2. Антоний (Храповицкий), митрополит. Ф. М. Достоевский как проповедник возрождения // Евангелие Достоевского: в 3 т. - Тобольск: Общественный благотворительный фонд «Возрождение Тобольска», 2017. - Т. 3: Свидетельства. Критика. Богословие. - С. 99-377.

3. Бахтин М. М. Эстетика словесного творчества. - М.: Искусство, 1979. $-424 \mathrm{c}$.

4. Бочаров С. Г. Чехов и философия // Вестник истории, литературы, искусства. - М., 2006. - Т. 3. - С. 146-159.

5. Громов М. П. Книга о Чехове. - М.: Современник, 1989. - 384 с.

6. Зусева-Озкан В. Б. Инвариантная структура и типология метаромана // Вестник РГГУ. Серия: История. Филология. Культурология. Востоковедение. - 2007. - № 7. - С. 35-44.

7. Зусева-Озкан В. Б. «Дон Кихот» как первый образец жанра метаромана // Известия Российской академии наук. Серия литературы и языка. 2012. - T. 71. — № 5. - С. 3-22. 
8. Зусева-Озкан В. Б. Историческая поэтика метаромана. - M.: Intrada, 2014. - $488 \mathrm{c}$.

9. Захаров В. Н. «Братья Карамазовы»: метафизика текста // "Die Brüder Karamasow": Dostojeewskijs letzter roman in heutiger sicht: IX symposiums der Internationalen Dostojewskij-Gesellschaft. — Dresden: Dresden University Press, 1997. - S. 213-227. (a)

10. Захаров В. Н. Роман // Достоевский: эстетика и поэтика: словарь справочник / отв. ред. Г. К. Щенников. - Челябинск: Металл, 1997. — C. 211-213. (b)

11. Захаров В. Н. Христианский реализм в русской литературе (постановка проблемы) // Проблемы исторической поэтики. - 2001. - Вып. 6. C. 5-20 [Электронный ресурс]. — URL: http://poetica.pro/journal/article. php?id=2511. (07.09.2018) DOI: 10.15393/j9.art.2001.2511

12. Захаров В. Н. Умиление как категория поэтики Ф. М. Достоевского // Теория традиции: христианство и русская словесность: коллект. моногр. - Ижевск: Изд-во «Удмуртский университет», 2009. - С. 163-185.

13. Захаров В. Н. Имя автора - Достоевский. Очерк творчества. - М.: Индрик, 2013. - 456 с.

14. Иерофей (Влахос), митрополит. Православная духовность / пер. с новогреческого. - М.: Свято-Троицкая Сергиева Лавра, 2009. - 136 с.

15. Карасев Л. Достоевский и Чехов. Неочевидные смысловые структуры. - М.: Языки славянских культур, 2016. - 336 с.

16. Карякин Ю. Ф Достоевский - Чехов // Карякин Ю. Достоевский и Апокалипсис. - M., 2009 [Электронный ресурc]. - URL: https:// public.wikireading.ru/97562 (17.02.2019).

17. Кубасов А. В. Проза А. П. Чехова: искусство стилизации. - Екатеринбург: Урал. гос. пед. ун-т, 1998. - 399 с.

18. Назиров Р. Г. Достоевский и Чехов: Преемственность и пародия // Назиров Р. Г. Русская классическая литература: сравнительно-исторический подход. Исследования разных лет: сб. ст. - Уфа: РИО БашГУ, 2005. - С. 159-168.

19. Николаева О. Мучитель наш Чехов // Николаева О. Прямая речь. Откровенно о главном. - М.: Данилов мужской монастырь, 2015. C. $116-134$.

20. Озкан В. Б. Метароман как проблема исторической поэтики: дис. ... д-ра филол. наук / Рос. гос. гуманитар. ун-т. - М., 2013. - 570 с.

21. Полоцкая Э. А. Антон Чехов // Русская литература рубежа веков (1890-е - начало 1920-х годов). - М.: ИМЛИ РАН, 2000. - Кн. 1. C. $390-456$.

22. Пращерук Н. В. В «школе сокрушения»: о современной духовной прозе // Христианство и русская литература. - СПб.: Наука, 2016. Сб. 8. - С. 401-422. (a)

23. Пращерук Н. В. Опыт «очищения сердца» в святоотеческом понимании: о повести Е. Домбровской «Весна души. Страницы жизни рабы Божией Анны» // Проблемы исторической поэтики. - Петрозаводск, 
2016. - Вып. 14. - С. 441-455 [Электронный ресурc]. - URL: http:// poetica.pro/fi les/redaktor_pdf/1482829654.pdf(15.07.2018). DOI: 10.5393/ j9.art.2016.3842 (b)

24. Пращерук Н. В. Аскетический опыт самопознания и проблема творчества: о повести Е. Домбровской «Весна души. Страницы рабы Божией Анны» // Церковь. Богословие. История. - Екатеринбург: Екатеринбургская духовная семинария, 2017. - С. 180-186.

25. Пращерук Н. В. Современная духовная проза: традиции, смыслы, поэтика. - Екатеринбург: Изд-во Урал. ун-та, 2018. - 110 с. (а)

26. Пращерук Н. В. Христианский метароман Е. Р. Домбровской «Путь открылся... Чехов. Духовные странствия Тимофея диакона» // Проблемы исторической поэтики. - Петрозаводск, 2018. - Т. 16. — № 3. C. 222-227 [Электронный pecypc]. - URL: http://poetica.pro/files/ redaktor_pdf/1550661312.pdf(15.07.2018). DOI: 10.15393/j9.art.2018.5642 (b)

27. Степанян К. «Братья Карамазовы»: лик земной и вечная истина // Роман Ф. М. Достоевского «Братья Карамазовы»: современное состояние изучения / РАН, Ин-т мировой лит. им. А. М. Горького, Комис. по изучению творчества Ф. М. Достоевского; под ред. Т. А. Касаткиной. - М.: Наука, 2007. - С. 711-731.

28. Чотчаева М. Ю. Художественная концепция человека в творчестве $Ф$. М. Достоевского и А. П. Чехова: На материале произведений «Записки из Мертвого дома» и «Остров Сахалин»: дис. ... канд. филол. наук: 10.01.01. - Краснодар, 2001. - 150 с.

29. Шестов Л. Творчество из ничего (А. П. Чехов) // А. П. Чехов: pro et contra. Творчество А. П. Чехова в русской мысли конца XIX - нач. ХХ в.: Антология / сост. И. Н. Сухих. - СПб.: РХГИ, 2002. - С. 566-598.

30. Lowenkron D. H. The Metaroman // College English. - Vol. 38. - No. 4 (Dec., 1976). - Pp. 343-355 [Электронный pecypc]. — URL: https://www.jstor. org/stable/376420?seq=1\#page_scan_tab_contents (15.07.2018). 
Natal'ya V. Prashcheruk

Ural Federal University named after the first

President of Russia B. N. Yeltsin

(Yekaterinburg, Russian Federation)

pnv1108@gmail.com

\title{
The Dialogue with Dostoevsky in the Novel by E. R. Dombrovskaya "The Way is Open... Chekhov. Spiritual Wanderings of Timofei the Deacon"
}

\begin{abstract}
The article studies the dialogue with Dostoevsky developing in Dombrovskaya's christian metaroman "The way is open... Chekhov. Spiritual wanderings of Timofei the Deacon". It is shown that the dialogue is of an extensive, systematic and multidimensional character. It is carried on at all the levels of the artistic system of the novel: an author's message, method, genre, plot, characters system - and allows gaining a hermeneutic experience. In a dialogical correlation of Chekhov and Dostoevsky it is disclosed that both writers have in common the adherence to the evangelic spirit that helps them to be theologically precise/ accurate while judging and making emphases. However, while Dostoevsky interested primarily in the problem of destruction of the religious consciousness and testing the man on the way of freedom without God, disproves the principles and meanings of the Christian doctrine, Chekhov's spiritual realism that highlights the "movement of an essential layer" in the terms of the everyday life of the man "emanates silence, lives off an inner word". Besides, Chekhov as a child of his time feels better the danger of Pharisaism. The dialogue with Dostoevsky is carried on not only in philological sketches of the main hero, but is reflected in the destinies of the novel's characters, in understanding of the spiritual conditions of modern Russia. The article, based on the reasoning of E. R. Dombrovskaya, for the first time asserts that Chekhov's concept of the beauty is also interpreted both as the extension of a famous Dostoevsky's principle and as its enrichment with new inner meanings.
\end{abstract}

Keywords: Chekhov, Dostoevsky, dialogue, Christian metaroman, Christian realism, plot, hero, understanding of the beauty

About the author: Prashcheruk Natal'ya V. - Doctor of Philology, Professor of the Department of Russian and Foreign Literature, Ural Federal University named after the first President of Russia B. N. Yeltsin (ul. Mira 19, Yekaterinburg, 620002, Russian Federation)

Received: March 14, 2019

Date of publication: October 18, 2019

For citation: Prashcheruk N. V. The Dialogue with Dostoevsky in the Novel by E. R. Dombrovskaya "The Way is Open... Chekhov. Spiritual Wanderings of Timofei the Deacon". In: Problemy istoricheskoy poetiki [The Problems of 
The Dialogue with Dostoevsky in the Novel by E. R. Dombrovskaya... 363

Historical Poetics], 2019, vol. 17, no. 4, pp. 345-365. DOI: 10.15393/j9. art.2019.6201 (In Russ.)

\section{References}

1. Annenskiy I. F. Knigi otrazheniy [Books of Reflections]. Moscow, Nauka Publ., 1979. 679 p. (In Russ.)

2. Antoniy (Khrapovitskiy), Metropolitan. F. M. Dostoevsky as a Preacher of the Renaissance. In: Evangelie Dostoevskogo: $v 3$ tomakh [Dostoevsky's Gospel: in 3 Vols]. Tobolsk, Obshchestvennyy blagotvoritel'nyy fond Vozrozhdenie Tobol'ska Publ., 2017, vol. 3, pp. 99-377. (In Russ.)

3. Bakhtin M. M. Estetika slovesnogo tvorchestva [Aesthetics of Verbal Creation]. Moscow, Iskusstvo Publ., 1979. 424 p. (In Russ.)

4. Bocharov S. G. Chekhov and Philosophy. In: Vestnik istorii, literatury, iskusstva [Bulletin of History, Literature, Arts]. Moscow, 2006, vol. 3, pp. 146-159. (In Russ.)

5. Gromov M. P. Kniga o Chekhove [A Book About Chekhov]. Moscow, Sovremennik Publ., 1989. 384 p. (In Russ.)

6. Zuseva-Ozkan V. B. The Invariant Structure and Typology of Metaroman. In: Vestnik RGGU. Seriya: Istoriya. Filologiya. Kul'turologiya. Vostokovedenie [RSUH / RGGU Bulletin. Series: History. Philology. Cultural Studies. Oriental Studies], 2007, no. 7, pp. 35-44. (In Russ.)

7. Zuseva-Ozkan V. B. "Don Quixote" as the First Sample of the Genre of Metaroman. In: Izvestiya Rossiyskoy akademii nauk. Seriya literatury i yazyka [The Bulletin of the Russian Academy of Sciences: Studies in Literature and Language], 2012, vol. 71, no. 5, pp. 3-22. (In Russ.)

8. Zuseva-Ozkan V. B. Istoricheskaya poetika metaromana [The Historical Poetics of a Metaroman]. Moscow, Intrada Publ., 2014. 488 p. (In Russ.)

9. Zakharov V. N. "The Brothers Karamazov": the Metaphysics of the Text. In: "Die Brüder Karamasow": Dostojeewskijs letzter roman in heutiger sicht: IX symposiums der Internationalen Dostojewskij-Gesellschaft ["The Brothers Karamazov": Dostoevsky's Last Novel for the Present: the 9th Symposium of the International Dostoevsky Society]. Dresden, Dresden University Press Publ., 1997, pp. 213-227. (In Russ.) (a)

10. Zakharov V. N. Novel. In: Dostoevskiy: estetika i poetika: slovar' spravochnik [Dostoevsky: Aesthetics and Poetics. Dictionary and Reference Book]. Chelyabinsk, Metall Publ., 1997, pp. 211-213. (In Russ.) (b)

11. Zakharov V. N. Christian Realism in Russian Literature (Problem Statement). In: Problemy istoricheskoy poetiki [The Problems of Historical Poetics], 2001, issue 6, pp. 5-20. Available at: http://poetica.pro/journal/article.php?id=2511 (accessed on September 7, 2018). DOI: 10.15393/j9.art.2001.2511. (In Russ.)

12.Zakharov V. N. Umilenie ("Tenderness") as the Category of Dostoevsky's Poetics. In: Teoriya traditsii: khristianstvo i russkaya slovesnost' [Theory of Tradition: Christianity and Russian Literature]. Izhevsk, Udmurt State University Publ., 2009, pp. 163-185. (In Russ.) 
13. Zakharov V. N. Imya avtora - Dostoevskiy. Ocherk tvorchestva [The Author's Name is Dostoevsky. An Essay on the Creative Work]. Moscow, Indrik Publ., 2013. 456 p. (In Russ.)

14. Ierofey (Vlakhos), Metropolitan. Pravoslavnaya dukhovnost' [Orthodox Spirituality]. Moscow, The Holy Trinity-St. Sergius Lavra Publ., 2009. 136 p. (In Russ.)

15. Karasev L. Dostoevskiy i Chekhov. Neochevidnye smyslovye struktury [Dostoevsky and Chekhov. Unevident Semantic Structures]. Moscow, Yazyki slavyanskikh kul'tur Publ., 2016. 336 p. (In Russ.)

16. Karyakin Yu. Dostoevsky - Chekhov. In: Karyakin Yu. Dostoevskiy i Apokalipsis [Karyakin Yu. Dostoevsky and the Apocalypse]. Moscow, 2009. Available at: https://public.wikireading.ru/97562 (accessed on February 17, 2019). (In Russ.)

17. Kubasov A. V. Proza A. P. Chekhova: iskusstvo stilizatsii [Chekhov's Prose: the Art of Stylization]. Yekaterinburg, Ural State Pedagogical University Publ., 1998. 399 p. (In Russ.)

18. Nazirov R. G. Dostoevsky and Chekhov: Continuity and Parody. In: Nazirov R. G. Russkaya klassicheskaya literatura: sravnitel'no-istoricheskiy podkhod. Issledovaniya raznykh let: sbornik statey [Nazirov R. G. Russian Classical Literature: a Comparative Historical Approach. Researches of Different Years: A Collection of Articles]. Ufa, Bashkir State University Publ., 2005, pp. 159-168. (In Russ.)

19. Nikolaeva O. Chekhov, our Torturer. In: Nikolaeva O. Pryamaya rech'. Otkrovenno o glavnom [Nikolaeva O. A Direct Speech. Frankly About the Main]. Moscow, Danilov Monastery Publ., 2015, pp. 116-134. (In Russ.)

20. Ozkan V. B. Metaroman kak problema istoricheskoy poetiki: dis. ... d-ra filol. nauk [A Metaroman as a Problem of the Historical Poetics. PhD. philol. sci. diss.]. Moscow, 2013. 570 p. (In Russ.)

21. Polotskaya E. A. Anton Chekhov. In: Russkaya literatura rubezha vekov (1890-e - nachalo 1920-kh godov) [Russian Literature of the Turn of the Century (the 1890s - Early 1920s)]. Moscow, A. M. Gorky Institute of World Literature of the RAS Publ., 2000, book 1, pp. 390-456. (In Russ.)

22.Prashcheruk N. V. In the "School of Destruction": On Contemporary Spiritual Prose. In: Khristianstvo i russkaya literatura [Christianity and Russian Literature]. St. Petersburg, Nauka Publ., 2016, collection 8, pp. 401-422. (In Russ.) (a)

23. Prashcheruk N. V. An Experience of "Heart Purification" in Patristic Understanding: E. Dombrovskaya's Story "The Spring of Soul. Life Scenes of Ann, the Servant of God". In: Problemy istoricheskoy poetiki [The Problems of Historical Poetics]. Petrozavodsk, 2016, issue 14, pp. 441-455. Available at: http://poetica.pro/fi les/redaktor_pdf / 1482829654.pdf (accessed on July 15, 2018). DOI: 10.5393/ j9.art.2016.3842 (In Russ.) (b)

24. Prashcheruk N. V. The Ascetic Experience of Self-Knowledge and the Problem of Creative Process: On E. Dombrovskaya's Story "The Spring of Soul. Life Scenes of Ann, the Servant of God”. In: Tserkov'. Bogoslovie. Istoriya [Church. 
The Dialogue with Dostoevsky in the Novel by E. R. Dombrovskaya... 365

Theology. History]. Yekaterinburg, The Yekaterinburg Theological Seminary Publ., 2017, pp. 180-186. (In Russ.)

25. Prashcheruk N. V. Sovremennaya dukhovnaya proza: traditsii, smysly, poetika [Modern Spiritual Prose: Traditions, Meanings, Poetics]. Yekaterinburg, Ural Federal University Publ., 2018. 110 p. (In Russ.) (a)

26. Prashcheruk N. V. Christian Metaroman by E. R. Dombrovskaya "The Way Is Free... Chekhov. Spiritual Wanderings of Timofey the Deacon". In: Problemy istoricheskoy poetiki [The Problems of Historical Poetics]. Petrozavodsk, 2018, vol. 16, no. 3, pp. 222-227. Available at: http://poetica.pro/files/redaktor_pdf/1550661312.pdf (accessed on July 15, 2018). DOI: 10.15393/j9. art.2018.5642 (In Russ.) (b)

27. Stepanyan K. "The Brothers Karamazov" - the Earthly Image, and the Eternal Truth. In: Roman F. M. Dostoevskogo "Brat'ya Karamazovy»: sovremennoe sostoyanie izucheniya [Dostoevsky's Novel "The Brothers Karamazov": The Current State of Studying]. Moscow, Nauka Publ., 2007, pp. 711-731. (In Russ.)

28. Chotchaeva M. Yu. Khudozhestvennaya kontseptsiya cheloveka v tvorchestve F. M. Dostoevskogo i A. P. Chekhova: Na materiale proizvedeniy "Zapiski iz Mertvogo doma» $i$ "Ostrov Sakhalin»: dis. ... kand. filol. nauk [An Artistic Concept of Man in the Works of F. M. Dostoevsky and A. P. Chekhov: Based on the Material of the Writings "Notes from the Dead House" and "Island Sakhalin". PhD. philol. sci. diss.]. Krasnodar, 2001. 150 p. (In Russ.)

29. Shestov L. The Creative Works from Nothing (A. P. Chekhov). In: A. P. Chekhov: pro et contra. Tvorchestvo A. P. Chekhova v russkoy mysli kontsa XIXnachala XX v.: Antologiya [A. P. Chekhov: Pro et Contra. The A. P. Chekhov's Creativity in the Russian Thought of the Late 19th - Early 20th Century: Anthology]. St. Petersburg, Russian Christian Humanitarian Institute Publ., 2002, pp. 566-598. (In Russ.)

30.Lowenkron D. H. The Metaroman. In: College English, vol. 38, no. 4, December, 1976, pp. 343-355. Available at: https://www.jstor.org/stable/376420?se$\mathrm{q}=1 \#$ page_scan_tab_contents (accessed on July 15, 2018) (In Russ.) 